\title{
Colonisation of leaf litter by aquatic invertebrates in an Atlantic Forest stream
}

\author{
Oliveira, VC. *, Gonçalves, EA. and Alves, $R G$. \\ Laboratório de Invertebrados Bentônicos, Departamento de Zoologia, Instituto de Ciências Biológicas, \\ Universidade Federal de Juiz de For a - UFJF, Rua José Lourenço Kelmer, s/n, Campus Universitário, \\ São Pedro, CEP 36036-900, Juiz de Fora, MG, Brasil \\ *e-mail: vco.vivian@gmail.com
}

Received June 13, 2012 - Accepted March 13, 2013 - Distributed May 31, 2014

(With 3 figures)

\begin{abstract}
Riparian vegetation along streams in the Atlantic Forest in Brazil contributes to the formation of a highly heterogeneous leaf litter in streambeds. To investigate the structure and composition of the aquatic invertebrate community during the process of leaf decomposition of two plant species present along the banks of the stream studied, 21 plastic mesh bags containing 2.5g (dry weight) of leaf matter from each species (Alchornea glandulosa (Vell) and Cabralea canjerana End. and Poeppig), for a total of 5.0g, were placed in the streambed. Three bags were removed after 3, 6, 9, 12, 24, 48 and 96 days. The taxonomic density was negatively correlated with the remaining weight. The high density of collector organisms, such as Chironomidae, Oligochaeta and Amphipoda, on the last day of incubation, probably occurred due to the increased amount of fine organic matter in the more advanced decomposition stages. The highest $\alpha$ diversity (Shannon-Wiener) values were observed for the 3rd and 96th days of the experiment, while the $\beta$ diversity values showed that these days presented the highest variation in the taxonomic composition, thus presenting a different faunistic composition. This study showed that the trophic structure and composition of aquatic invertebrates changes during the decomposition of leaf litter. The faunistic abundance and diversity observed in this study indicate that the entrance of material from plants growing along streams provides favorable conditions for the colonisation and establishment of invertebrates in lower-order streams, and thus points to the need to preserve riparian vegetation.
\end{abstract}

Keywords: riparian vegetation, allochthonous materials, decomposition.

\section{Colonização de folhiço por invertebrados aquáticos em um córrego de Mata Atlântica}

\section{Resumo}

A vegetação ripária presente ao longo de córregos em áreas de Mata Atlântica contribui para a formação de serapilheira bastante heterogênea no leito de córregos. Com o objetivo de investigar a estrutura e composição da comunidade de invertebrados aquáticos durante o processo de degradação de detritos foliares de duas espécies vegetais presentes nas margens do córrego, 21 sacos de tela plástica contendo $2.5 \mathrm{~g}$ de peso seco de cada espécie vegetal (Alchornea glandulosa (Vell) e Cabralea canjerana End. \& Poeppig), totalizando 5.0g, foram colocados no leito do córrego. Três réplicas foram retiradas após 3, 6, 9, 12, 24, 48 e 96 dias. A densidade taxonômica esteve negativamente correlacionada com o peso remanescente. A elevada densidade de organismos coletores, como Chironomidae, Oligochaeta e Amphipoda, no último dia de incubação ocorreu provavelmente devido ao aumento de matéria orgânica particulada fina nas etapas mais avançadas da decomposição. Os maiores valores de diversidade $\alpha$ foram observados para o $3^{\circ}$ e $96^{\circ}$ dias de experimento, enquanto a diversidade $\beta$ mostrou que esses dois dias apresentaram a maior variação na composição taxonômica, apresentando, portanto uma composição faunística diferente. Este estudo mostrou que ocorreu modificação na estrutura trófica e na composição de invertebrados aquáticos durante o processo degradativo dos detritos foliares. A abundância e diversidade faunística observada neste estudo indicam que a entrada de material vegetal de origem terrestre propiciam condições favoráveis para a colonização e estabelecimento dos invertebrados em córregos de baixa ordem e, portanto, reforça a necessidade de preservação da vegetação ripária.

Palavras-chave: vegetação ripária, material alóctone, decomposição. 


\section{Introduction}

The riparian vegetation along streams in preserved areas of the Atlantic Forest in Brazil is composed of a great variety of species (Sanchez et al., 1999) that contribute to the formation of a highly heterogeneous leaf litter in the beds of these lotic environments (Swan and Palmer, 2004). Shallow and narrow streams with low water flow have retention features such as stones, trunks and branches (Wohl et al., 1995) that make them propitious environments for the accumulation of leaves falling mainly from riparian vegetation (Carvalho and Uieda, 2010). This detritus is normally used as a source of food and shelter by aquatic invertebrates.

The substrates present in streams, such as sand, stones and plant matter, have a considerable influence on the composition and structure of benthic fauna (Reice, 1980; Sanseverino and Nessimian, 2001), affecting the abundance and spatial distribution of organisms. Plant material of allochthonous origin accumulated in streambeds promotes spatial heterogeneity, increases the food availability for aquatic invertebrates (Francischetti et al., 2004), provides shelter against predators (Oberndorfer et al., 1984) and triggers environmental changes (Lancaster and Hildrew, 1993), making this material an important component in preserved lotic systems.

The plant material that falls into streams is colonised by microorganisms and aquatic invertebrates, either in series or simultaneously (Allan and Castillo, 2007). Shredding and borrowing invertebrates, together with decomposer microorganisms (fungi and bacteria) and physical abrasion, convert coarse organic matter (particles $>1 \mathrm{~mm}$ ) into fine organic matter $(<1 \mathrm{~mm}$ and $>0.5 \mathrm{~mm})$ (Graça, 2001; Kominoski et al., 2011). The structural and biochemical modification of leaf litter during the decomposition process alters the amount of available organic matter, the microbiota and the composition of the aquatic invertebrate community (Gonçalves Júnior et al., 2004; Moretti et al., 2007).

The colonisation of leaf litter by invertebrates in lotic environments has attracted a good deal of academic interest in recent years due to its importance in understanding the ecological succession in these environments (Abelho, 2001; Galizzi and Marchese, 2007; Swan and Palmer, 2006). However, there are few such studies in tropical streams (Benstead, 1996; Gonçalves Júnior et al., 2006; Mathuriau and Chauvet, 2002; Moretti et al., 2007).

The aim of the present work was to investigate the structure and composition of the aquatic invertebrate community during the decomposition of leaf litter made up of a mixture of two species of plants present along the banks of the stream studied.

\section{Material and Methods}

\subsection{Study area}

The study was carried out in the Poço D'Anta Municipal Biological Reserve. It is classified as a fully protected conservation unit and covers an area of about 277 hectares in the municipality of Juiz de Fora, Minas Gerais state, in southeastern Brazil (21 $444^{\prime} 23^{\prime \prime}-21^{\circ} 45^{\prime} 51^{\prime \prime} \mathrm{S}$ and $43^{\circ} 18^{\prime} 29^{\prime}$ '$43^{\circ} 19^{\prime} 9$ 'W) at an altitude of about $850 \mathrm{~m}$. The Reserve is a fragment with typical Atlantic Forest vegetation in a secondary regeneration stage, partly inserted in an urban zone (Sousa, 2008).

The experiment was conducted along a five-metre stretch of a first-order stream located at the coordinates $\mathrm{S}$ $21^{\circ} 44^{\prime} 38^{\prime \prime}$ and W $48^{\circ} 18^{\prime} 50^{\prime \prime}$, with the physical characteristics presented in Table 1.

\subsection{Collection and identification of leaves}

The species Alchornea glandulosa Endl and Poeppig (Euphorbiaceae) and Cabralea canjerana (Vell) Mart (Meliaceae) were chosen for the colonisation experiment because they grow abundantly along the stream's banks, could be accessed easily and are listed among the main bush-tree species present in riparian vegetation in Brazil outside the Amazon region (Rodrigues and Nave, 2001).

Green leaves of the two species were gathered and dried in a drying chamber at $60{ }^{\circ} \mathrm{C}$ for 48 hours. Then a mixture of $2.5 \mathrm{~g}$ (dry weight) of leaf matter of each species was placed in litter bags measuring $10 \mathrm{~cm}$ in width and $15 \mathrm{~cm}$ in length, with $1.0 \mathrm{~cm}$ mesh. A total of 21 litter bags were placed in the streambed near the substrate and secured to PVC tubes partially buried along the banks, in three replicates. The bags were removed after $3,6,9,12$, 24,48 and 96 days and were placed individually in plastic sacks containing $4 \%$ formaldehyde. The experiment was conducted between July and October 2008.

The samples were passed through a sieve with $0.21 \mathrm{~mm}$ mesh and the organisms found were sorted under a stereoscopic microscope. The taxonomic identification followed McCafferty (1981), Merritt and Cummins (1984), Fernández and Domínguez (2001), Carvalho and Calil (2000) and Costa et al. (2006).

The remaining plant matter was dried in the same chamber at $60{ }^{\circ} \mathrm{C}$ until constant weight to calculate the weight loss of the leaves.

Each time the bags were removed from the stream the water temperature, depth, speed and flow rate were measured, along with the stream width. The speed was measured with a small float and the flow by calculating the cross-sectional area and multiplying it by the average speed in the section of the stream (Martinelli and Krusche, 2007).

Table 1. Physical characteristics of the stream segment where the experiment was conducted (between July and October 2008) in the Poço D'Anta Municipal Biological Reserve, Juiz de Fora - MG.

\begin{tabular}{lr}
\hline \multicolumn{1}{c}{ Physical characteristics } & \multicolumn{1}{c}{ Values } \\
\hline Water depth $(\mathrm{cm})$ & $6.58 \pm 2.37$ \\
Stream width $(\mathrm{m})$ & $1.80 \pm 0.45$ \\
Water surface velocity $(\mathrm{m} / \mathrm{s})$ & $0.29 \pm 0.08$ \\
Water flow $\left(\mathrm{m}^{3} / \mathrm{s}\right)$ & $0.09 \pm 0.01$ \\
Water temperature $\left({ }^{\circ} \mathrm{C}\right)$ & $17.94 \pm 2.23$ \\
\hline
\end{tabular}




\subsection{Analysis of the data}

The dry weight loss rate of the leaf litter $(\mathrm{k})$ was calculated by applying the formula $\mathrm{W}_{\mathrm{t}}=\mathrm{W}_{0} \cdot \mathrm{e}^{\mathrm{kt}}$, where $\mathrm{W}_{0}$ is the initial biomass at $\mathrm{t}_{0}=5 \mathrm{~g}$ and $\mathrm{W}_{\mathrm{t}}$ is the biomass at the removal times of $\mathrm{t}=3,6,9,12,24,48$ and 96 days. According to Gonçalves Júnior et al. (2014), the weight loss in this type of experiment can be classified in Brazilian systems as slow $\left(\mathrm{k}<0.0041 \mathrm{~d}^{-1}\right)$, intermediate $(0.0041<$ $\left.\mathrm{k}<0.0173 \mathrm{~d}^{-1}\right)$ or rapid $\left(\mathrm{k}>0.0173 \mathrm{~d}^{-1}\right)$. However, these values can range depending on the environment.

The aquatic invertebrate fauna was analysed by taxon density (number of individuals per gram of dry weight average of three samples), relative density (\%), taxonomic richness, Pielou evenness, $\alpha$ diversity (Shannon-Wiener), $\beta$ diversity and percentage of functional feeding groups. Chironomidae (Diptera) and Hydroptilidae (Trichoptera) were not classified into functional feeding groups because they have diversified food habits, being removed from the analysis.

The $\alpha$ diversity was calculated for each day of bag removal according to the Shannon-Wiener diversity index. The $\beta$ diversity measures the change or rate of substitution in the composition of taxa from one site to another along a space or time gradient (Magurran, 2004). In this work we used the Whittaker index to calculate the faunistic substitution rate between the bag removal days. This index regards the total richness between samples and the average richness.

The Kruskal-Wallis statistical test was employed to verify the variation of the mean invertebrate density, Shannon-Wiener diversity, Pielou evenness, taxonomic richness values and functional feeding groups among the bag removal days. The correlation between the remaining dry weight and average taxonomic density was measured by the Pearson correlation coefficient with logged data. All these analyses were carried out using the BIOESTAT. 5.0 program (Ayres et al., 2007).

\section{Results}

The bags containing the leaf litter lost weight rapidly during the experiment $(\mathrm{k}>0.01)$. On the $96^{\text {th }}$ day only $8 \%$ of the initial dry weight remained. The average invertebrate density increased progressively $(H=22.06 ; p<0.01)$, reaching a maximum value on the 96 th day $(764.22$ ind/g) (Figure 1). The taxonomic density was negatively correlated with the remaining dry weight of the leaf litter $(\mathrm{r}=-0.93 ; \mathrm{p}<0.01)$.

The indices of $\alpha$ diversity Shannon-Wiener $(\mathrm{H}=12.50$; $\mathrm{p}=0.05)$ and Pielou evenness $(\mathrm{H}=15.90 ; \mathrm{p}=0.01)$ were highest in the first and last day of the experiment. The taxonomic richness was higher on the $48^{\text {th }}$ day $(\mathrm{S}=22 ; \mathrm{H}$ $=3.97 ; \mathrm{p}=0.04)$ and $96^{\text {th }}$ day $(\mathrm{S}=23 ; \mathrm{H}=3.97 ; \mathrm{p}=0.04)$ than on the $3^{\text {rd }}$ day $(S=15)$ of the experiment (Table 2).

During the first 48 days of colonisation, the predominant organisms were Chironomidae larvae (> 50\%), composing $84.21 \%$ of the total after 9 days of the experiment. On the $96^{\text {th }}$ day, their participation had fallen to $15.35 \%$, while there was an increase in the percentages of other orders: other Diptera (17\%), Amphipoda (23.23\%) and Oligochaeta (31.89\%) (Figure 2).

The percentage of functional feeding groups changed during the days of bag removal (Figure 3). Scrapers were more representative at the start of colonisation period and decreased throughout the experiment $(H=17.39 ; \mathrm{p}<0.01)$. Collectors were above $38 \%$ during all the days $(\mathrm{H}=6.08$; $\mathrm{p}=0.41)$ and shredders had higher percentages between 24 and 48 days the colonisation $(\mathrm{H}=16.44 ; \mathrm{p}<0.01)$.

The $\beta$ diversity (Table 3 ) showed higher variation in the taxonomic composition between the start ( 3 days) and end (96 days) of the colonisation period $\left(\beta_{\mathrm{w}}=0.63\right)$ and indicated lower fauna substitution between consecutive days. It also showed lower values than 0.37 between each pair of consecutive days, as seen in Table 3 .

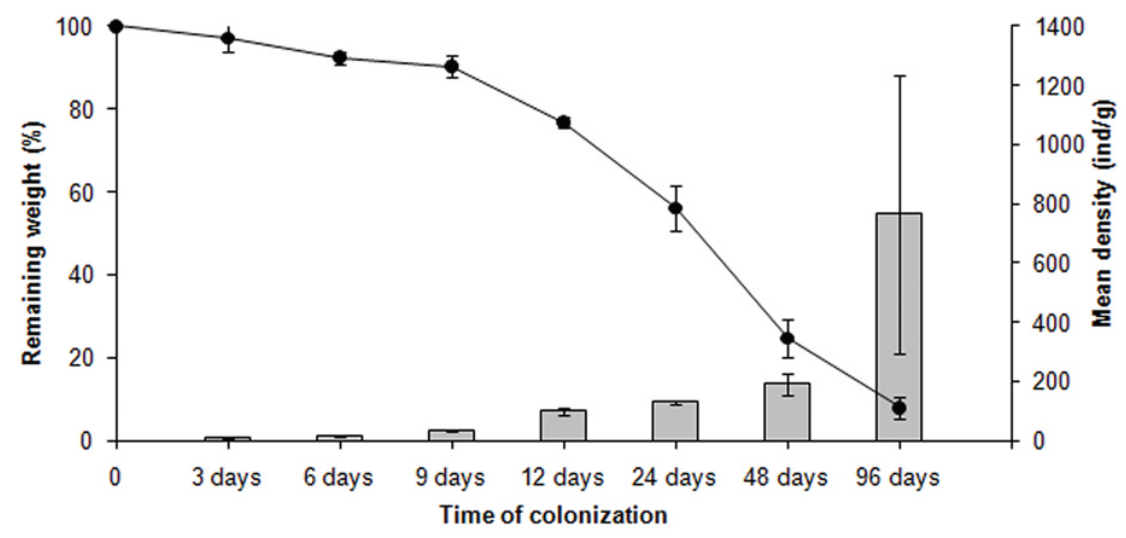

$\square$ Mean density (ind/g)

$\rightarrow-$ Remaining weight

Figure 1. Percentage of remaining weight $($ mean $\pm \mathrm{SD})$ and mean invertebrate density during decomposition of the leaf litter in a first-order stream in the Poço D'Anta Municipal Biological Reserve, Juiz de Fora - MG, Brazil. 
Table 2. Mean density \pm standard deviation, abundance, taxonomic richness, Shannon-Wiener diversity and Pielou evenness of aquatic invertebrates during decomposition of leaf litter in a first-order stream in the Poço D’Anta Municipal Biological Reserve, Juiz de Fora - MG, Brazil.

\begin{tabular}{|c|c|c|c|c|c|c|c|}
\hline & 3 days & 6 days & 9 days & 12 days & 24 days & 48 days & 96 days \\
\hline \multicolumn{8}{|l|}{ Plecoptera } \\
\hline Perlidae & $0.21 \pm 0.21$ & $0.22 \pm 0.21$ & $0.37 \pm 0.14$ & $0.77 \pm 0.89$ & $0.23 \pm 0.40$ & $1.00 \pm 1.01$ & $12.30 \pm 7.02$ \\
\hline Gripopterygidae & $0.07 \pm 0.11$ & $0.29 \pm 0.12$ & $0.29 \pm 0.25$ & $1.29 \pm 0.67$ & $1.83 \pm 0.90$ & $13.91 \pm 3.18$ & 0 \\
\hline \multicolumn{8}{|l|}{ Trichoptera } \\
\hline Calamoceratidae & 0 & $0.07 \pm 0.12$ & $0.22 \pm 0.38$ & $0.71 \pm 1.01$ & $2.59 \pm 1.98$ & $8.58 \pm 4.50$ & $2.03 \pm 2.00$ \\
\hline Hydrobiosidae & 0 & 0 & 0 & 0 & 0 & 0 & $1.39 \pm 2.41$ \\
\hline Helicopsychidae & $0.21 \pm 0.21$ & $0.21 \pm 0.37$ & 0 & $0.17 \pm 0.30$ & $0.27 \pm 0.46$ & $0.28 \pm 0.48$ & 0 \\
\hline Glossosomatidae & $1.04 \pm 0.97$ & $1.01 \pm 0.61$ & $0.44 \pm 0.58$ & $2.43 \pm 1.72$ & $2.29 \pm 0.58$ & $2.83 \pm 2.89$ & $5.59 \pm 6.36$ \\
\hline Polycentropodidae & $0.28 \pm 0.49$ & $0.14 \pm 0.12$ & $0.08 \pm 0.13$ & $0.35 \pm 0.61$ & 0 & $0.33 \pm 0.57$ & 0 \\
\hline Philopotamidae & 0 & 0 & 0 & 0 & 0 & 0 & $1.40 \pm 1.22$ \\
\hline Hydropsychidae & 0 & $0.07 \pm 0.13$ & 0 & 0 & $0.59 \pm 0.71$ & $1.15 \pm 1.25$ & $1.39 \pm 2.41$ \\
\hline Leptoceridae & $0.07 \pm 0.12$ & $0.07 \pm 0.12$ & $0.07 \pm 0.12$ & 0 & $1.99 \pm 1.40$ & $3.89 \pm 3.47$ & 0 \\
\hline Odontoceridae & 0 & 0 & 0 & 0 & 0 & $0.33 \pm 0.57$ & $1.33 \pm 2.31$ \\
\hline Hydroptilidae & $0.07 \pm 0.12$ & $0.50 \pm 0.49$ & $0.37 \pm 0.12$ & $8.01 \pm 2.57$ & $8.88 \pm 5.00$ & $1.23 \pm 1.08$ & 0 \\
\hline \multicolumn{8}{|l|}{ Ephemeroptera } \\
\hline Leptohyphidae & 0 & $0.14 \pm 0.25$ & $0.22 \pm 0.01$ & $0.26 \pm 0.00$ & $0.11 \pm 0.20$ & $0.28 \pm 0.48$ & $3.36 \pm 4.15$ \\
\hline Leptophlebiidae & $0.21 \pm 0.21$ & $0.29 \pm 0.25$ & $0.43 \pm 0.57$ & $1.32 \pm 1.33$ & $0.24 \pm 0.21$ & $2.31 \pm 1.42$ & $5.49 \pm 3.06$ \\
\hline Baetidae & $0.90+0.74$ & $0.50 \pm 0.12$ & $0.07 \pm 0.13$ & $0.94 \pm 1.63$ & $0.85 \pm 0.45$ & $1.76 \pm 1.99$ & $6.25 \pm 10.83$ \\
\hline Melanemerellidae & $0.13 \pm 0.23$ & $0.07 \pm 0.12$ & 0 & $0.09 \pm 0.15$ & $0.11 \pm 0.20$ & $0.45 \pm 0.78$ & 0 \\
\hline \multicolumn{8}{|l|}{ Diptera } \\
\hline Simuliidae & 0 & 0 & 0 & 0 & $0.57 \pm 1.00$ & 0 & $45.15 \pm 76.37$ \\
\hline Chironomidae & $4.18 \pm 2.89$ & $12.92 \pm 4.02$ & $28.29 \pm 3.62$ & $78.05 \pm 9.99$ & $101.33 \pm 17.87$ & $115.90 \pm 27.89$ & $117.31 \pm 34.09$ \\
\hline Dixidae & $0.07 \pm 0.12$ & $0.07 \pm 0.12$ & 0 & 0 & 0 & 0 & 0 \\
\hline Ceratopogonidae & 0 & 0 & $0.30 \pm 0.34$ & $0.17 \pm 0.15$ & 0 & $0.55 \pm 0.50$ & $82.07 \pm 88.60$ \\
\hline Empididae & 0 & 0 & 0 & 0 & $0.24 \pm 0.21$ & $0.55 \pm 0.95$ & 0 \\
\hline Tipulidae & 0 & 0 & 0 & 0 & 0 & $0.45 \pm 0.78$ & $2.75 \pm 2.39$ \\
\hline Diptera NI* & 0 & $0.07 \pm 0.12$ & $0.08 \pm 0.13$ & 0 & 0 & 0 & 0 \\
\hline \multicolumn{8}{|l|}{ Odonata } \\
\hline Megapodagrionidae & 0 & $0.07 \pm 0.12$ & $0.07 \pm 0.13$ & 0 & 0 & 0 & $1.33 \pm 2.31$ \\
\hline Libellulidae & 0 & 0 & $0.15 \pm 0.26$ & 0 & $0.13 \pm 0.23$ & 0 & 0 \\
\hline Calopterygidae & $0.13 \pm 0.23$ & $0.22 \pm 0.38$ & 0 & $0.78 \pm 0.52$ & $1.08 \pm 0.11$ & $2.76 \pm 1.93$ & $1.33 \pm 2.31$ \\
\hline Gomphidae & 0 & 0 & 0 & 0 & 0 & 0 & $0.71 \pm 1.23$ \\
\hline \multicolumn{8}{|l|}{ Heteroptera } \\
\hline Mesoveliidae & $0.07 \pm 0.12$ & 0 & 0 & 0 & 0 & $0.28 \pm 0.48$ & 0 \\
\hline Veliidae & 0 & 0 & 0 & $0.09 \pm 0.15$ & 0 & 0 & 0 \\
\hline \multicolumn{8}{|l|}{ Coleoptera } \\
\hline Hydrophilidae & 0 & $0.07 \pm 0.12$ & 0 & 0 & 0 & 0 & 0 \\
\hline Elmidae & 0 & 0 & $0.15 \pm 0.13$ & 0 & $0.23 \pm 0.40$ & 0 & $5.53 \pm 2.43$ \\
\hline Oligochaeta & 0 & $0.07 \pm 0.13$ & $0.67 \pm 0.46$ & $0.35 \pm 0.16$ & $0.34 \pm 0.34$ & $0.73 \pm 0.68$ & $243.74 \pm 227.67$ \\
\hline Amphipoda & $0.54 \pm 0.30$ & $0.86 \pm 0.42$ & $1.76 \pm 1.45$ & $2.44 \pm 0.96$ & $5.06 \pm 2.84$ & $30.45 \pm 26.97$ & $177.49 \pm 137.33$ \\
\hline Bivalvia & 0 & 0 & 0 & $0.09 \pm 0.15$ & 0 & 0 & $26.92 \pm 36.14$ \\
\hline Turbellaria & 0 & 0 & 0 & 0 & 0 & 0 & $15.80 \pm 13.69$ \\
\hline Hydrozoa & 0 & 0 & 0 & 0 & 0 & 0 & $3.55 \pm 6.14$ \\
\hline Abundance & 120 & 249 & 462 & 1132 & 1086 & 691 & 802 \\
\hline Richness & 15 & 21 & 18 & 18 & 20 & 22 & 23 \\
\hline $\begin{array}{l}\text { Shannon-Wiener } \\
\text { diversity }\end{array}$ & 2.07 & 1.37 & 0.82 & 0.93 & 0.99 & 1.48 & 1.98 \\
\hline Pielou evenness & 0.76 & 0.45 & 0.28 & 0.32 & 0.33 & 0.48 & 0.63 \\
\hline
\end{tabular}

$* \mathrm{NI}=$ Not identified. 


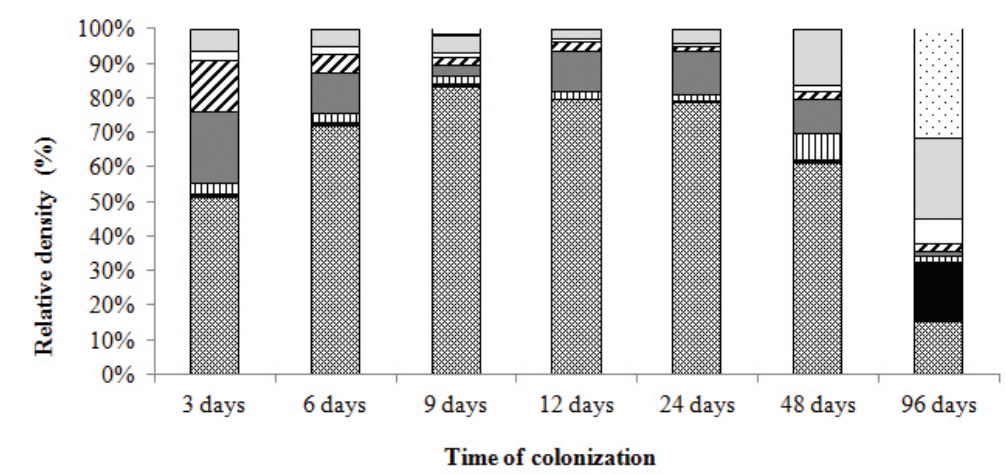

\begin{tabular}{|c|c|c|c|}
\hline Diptera Chironomidae & -Other Diptera & 口Plecoptera & $\square$ Trichoptera \\
\hline $\boldsymbol{E}$ Ephemeroptera & $\square$ Other groups & $\square$ Amphipoda & DOligochaeta \\
\hline
\end{tabular}

Figure 2. Relative density (\%) of aquatic invertebrates during decomposition of leaf letter in a first-order stream in the Poço D’Anta Municipal Biological Reserve, Juiz de Fora - MG, Brazil.

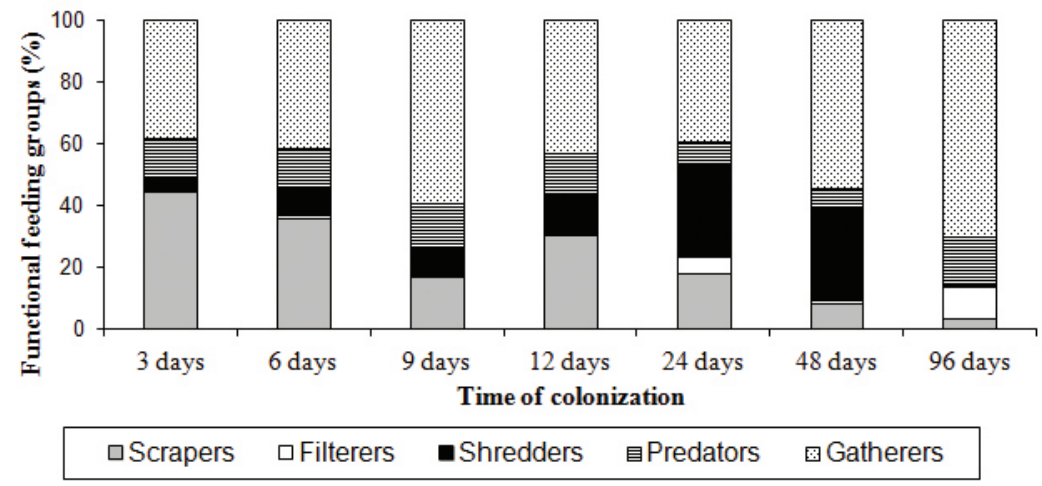

Figure 3. Functional feeding groups (\%) of aquatic invertebrates during decomposition of leaf litter in a first-order stream in the Poço D’Anta Municipal Biological Reserve, Juiz de Fora - MG, Brazil.

\section{Discussion}

In this study the steady increase in the density of Chironomidae larvae with time and the increase of Oligochaeta and Amphipoda on the last experiment day culminated in the peak invertebrate density. According to Allan and Castillo (2007), plant matter undergoes structural and biochemical changes during decomposition that propitiate the high density of collector groups, such as Oligochaeta and Amphipoda, which efficiently use food resources of the detritivore chain, mainly in the more advanced decomposition stages, due to the increase in fine organic matter (Capello et al., 2004; Ligeiro et al, 2010).

The predominance of Chironomidae at the start of the experiment can be explained by the high colonisation capacity of these larvae (Batzer and Wissinger, 1996). The Chironomidae are present in high density during the colonisation of organic detritus (Benstead, 1996; Gonçalves Júnior et al., 2003; Moretti et al., 2007) and tend to have generalist and opportunistic feeding habits (Silva et al., 2008), enabling them to colonise leaf litter regardless of the quality and/or decomposition time (Gonçalves Júnior et al., 2006).

The decrease in the percentage of scrapers along the experiment may be related to their feeding habits, because these organisms feed on periphyton adhered to the surface of the mineral or organic substrates (Wallace and Webster, 1996) and according to Mormul et al. (2006), after some days of the experiment, there may be a decrease of the percentage of scrapers because part of the substrate used begins to be lost due the reduction of leaves and consequent drifting of these fragments. The shredders have an important role in the conversion of coarse particulate organic matter into fine particulate organic matter (Graça, 2001). However, these organisms use leaf detritus as a food resource only after structural and/or biochemical changes that make them more palatable (Cummins et al., 1989), which might explain the highest percentage of shredders between 24 and 48 days of the experiment.

The lowest invertebrate richness was observed on the $3^{\text {rd }}$ day of colonisation, but the absence of dominant taxa contributed to one of the highest $\alpha$ diversity values obtained 
Table 3. Matrix of bw diversity among the days of the experiment during decomposition of leaf litter in a first-order stream in the Poço D’Anta Municipal Biological Reserve, Juiz de Fora - MG, Brazil.

\begin{tabular}{cccccccc}
\hline$\beta_{\mathbf{w}}$ & $\mathbf{3 ~ d a y s}$ & $\mathbf{6}$ days & $\mathbf{9}$ days & $\mathbf{1 2}$ days & $\mathbf{2 4}$ days & $\mathbf{4 8}$ days & $\mathbf{9 6}$ days \\
\hline 3 days & 0 & & & & & & \\
6 days & 0.22 & 0 & & & & & \\
9 days & 0.39 & 0.23 & 0 & & & & \\
12 days & 0.27 & 0.23 & 0.27 & 0 & & & \\
24 days & 0.31 & 0.22 & 0.26 & 0.26 & 0 & 0 & \\
48 days & 0.24 & 0.21 & 0.30 & 0.20 & 0.19 & 0.37 & 0 \\
96 days & 0.63 & 0.45 & 0.41 & 0.41 & 0.40 & 0.37 \\
\hline
\end{tabular}

during the experiment. During the succession process the structural and/or biochemical modifications of the litter permits colonisation by other taxa (Gonçalves Júnior et al., 2003), leading to greater richness and consequently increased diversity, as observed on the $96^{\text {th }}$ day of the experiment.

The highest $\beta$ diversity on the 3rd and 96th days of the experiment showed that on these two days the greatest variation in taxonomic composition occurred, indicating the substitution of fauna between the start and end of the colonisation. The substitution of aquatic invertebrates is possibly related to the different degrees of leaf fragmentation, leading to a change in the composition of invertebrate species due to their different biological needs (Kikuchi and Uieda, 2005).

This study showed, as expected, that the structure and composition of aquatic invertebrates changes during the decomposition of the leaf litter. The faunistic abundance and diversity observed in this study shows the importance of the entrance of streamside plant matter as a source of energy for the invertebrates in first-order streams and the need to preserve forest areas, mainly riparian vegetation.

Acknowledgements - We would like to thank the "Fundação de Apoio à Pesquisa do Estado de Minas Gerais" (FAPEMIG) for the financial support (CRA APQ-01285-08), the "Coordenação de Aperfeiçoamento de Pessoal de Nível Superior" (CAPES) and the "Conselho Nacional de Desenvolvimento Científico e Tecnológico" (CNPq) for the scholarships. We would also like to thank Dr. Arthur Valente for the identification of plant species.

\section{References}

ABELHO, M., 2001. From litterfall to breakdown in streams: a review. TheScientificWorldJournal, vol. 1, p. 656-680. http:// dx.doi.org/10.1100/tsw.2001.103. PMid:12805769

ALLAN, JD. and CASTILLO, MM., 2007. Stream Ecology: Structure and function of running waters. 2nd ed. Dordrecht: Springer. $236 \mathrm{p}$.

AYRES, M., AYRES-JUNIOR, M., AYRES, DL. and SANTOS, AAS., 2007. Software BioEstat: aplicações estatísticas nas áreas das Ciências Biológicas e Médicas. version 5.0. Belém: Sociedade Civil Mamirauá.

BATZER, DP. and WISSINGER, SA., 1996. Ecology of insect communities in nontidal wetlands. Annual Review of Entomology, vol. 41, no. 1, p. 75-100. http://dx.doi.org/10.1146/annurev. en.41.010196.000451. PMid:15012325

BENSTEAD, JP., 1996. Macroinvertebrates and the processing of leaf litter in a tropical stream. Biotropica, vol. 28, no. 3, p. 367-375. http://dx.doi.org/10.2307/2389200.

CARVALHO, EM. and UIEDA, VS., 2010. Input of litter in deforested and forested areas of a tropical headstream. Brazilian Journal of Biology, vol. 70, no. 2, p. 283-288. http://dx.doi. org/10.1590/S1519-69842010005000015. PMid:20379655

CAPELLO, S., MARCHESE, M. and DRAGO, E., 2004. Descomposición y colonización por invertebrados de hojas de Salix humboldtiana em la llanura aluvial del río Paraná Medio. Amazoniana, vol. 18, no. 1-2, p. 125-143.

CARVALHO, AL. and CALIL, ER., 2000. Chaves de identificação para as famílias de Odonata (Insecta) ocorrentes no Brasil, adultos e larvas. Papéis Avulsos de Zoologia, vol. 41, no. 15, p. 223-241.

COSTA, C., IDE, S. and SIMONKA, CE., 2006. Insetos Imaturos: Metamorfose e Identificação. Ribeirão Preto: Holos. 249 p.

CUMMINS, KW., WILZBACH, MA., GATES, DM., PERRY, JB. and TALIAFERRO, WB., 1989. Shredders and Riparian Vegetation. Bioscience, vol. 39, no. 1, p. 24-30. http://dx.doi. org/10.2307/1310804.

FERNÁNDEZ, HR. and DOMÍNGUEZ, E. (Ed.), 2001. Guía para la determinación de los artrópodos bentónicos sudamericanos. San Miguel de Tucumán: Editorial Universitária de Tucumán. 283 p.

FRANCISCHETTI, CN., SILVA, ER., SALLES, FF. and NESSIMIAN, JL., 2004. A Efemeropterofauna (Insecta: Ephemeroptera) do trecho ritral inferior do Rio Campo Belo, Itatiaia, RJ: composição e mesodistribuição. Lundiana, vol. 5, no. 1, p. 33-39.

GALIZZI, MC. and MARCHESE, M., 2007. Descomposición de hojas de Tessaria integrifolia (Asteraceae) y colonización por invertebrados en un cauce secundario del Río Paraná Medio. Interciencia, vol. 32, no. 8, p. 535-540.

GONÇALVES JÚNIOR, JF., ESTEVES, FA. and CALLISTO, M., 2003. Chironomids colonisation on Nymphaea ampla L. detritus during a degradative ecological succession experiment in a Brazilian coastal lagoon. Acta Limnologica Brasiliensia, vol. 15 , no. 2 , p. $21-27$.

GONÇALVES JÚNIOR, JF., SANTOS, AM. and ESTEVES, FA., 2004. The influence of the chemical composition of Typha domingensis and Nymphaea ampla detritus on invertebrate colonisation during decomposition in a Brazilian coastal lagoon. Hydrobiologia, vol. 527, no. 1, p. 125-137. http://dx.doi.org/10.1023/ B:HYDR.0000043190.49651.dc. 
GONÇALVES JÚNIOR, JF., FRANÇA, JS., MEDEIROS, AO., ROSA, CA. and CALLISTO, M., 2006. Leaf breakdown in a tropical stream. International Review of Hydrobiology, vol. 91, no. 2, p. 164-177. http://dx.doi.org/10.1002/iroh.200510826.

GONÇALVES JÚNIOR, JF., MARTINS, RT., OTTONI, BMP. and COUCEIRO, SRM., 2014. Uma visão sobre a decomposição foliar em sistemas aquáticos brasileiros. In HAMADA, N., NESSIMIAN, JL. and QUERINO, RB. Insetos Aquáticos na Amazônia Brasileira: taxonomia, biologia e ecologia. Manaus: Editora do INPA. p. 89-116.

GRAÇA, MAS., 2001. The role of invertebrates on leaf litter decomposition in streams - a review. International Review of Hydrobiology, vol. 86, no. 4-5, p. 383-393. http:// dx.doi.org/10.1002/1522-2632(200107)86:4/5<383::AIDIROH383>3.0.CO;2-D.

KIKUCHI, RM. and UIEDA, VS., 2005. Composição e distribuição dos macroinvertebrados em diferentes substratos de fundo de um riacho no município de Itatinga, São Paulo, Brasil. Entomología y Vectores, vol. 12, no. 2, p. 193-231. http://dx.doi.org/10.1590/ S0328-03812005000200006.

KOMINOSKI, JS., MARCZAK, LB. and RICHARDSON, JS., 2011. Riparian forest composition affects stream litter decomposition despite similar microbial and invertebrate communities. Ecology, vol. 92, no. 1, p. 151-159. http://dx.doi.org/10.1890/10-0028.1. PMid:21560685

LANCASTER, J. and HILDREW, AG., 1993. Flow refugia and the microdistribution of lotic macroinvertebrates. Journal of the North American Benthological Society, vol. 12, no. 4, p. 385-393. http://dx.doi.org/10.2307/1467619.

LIGEIRO, R., MORETTI, MS., GONÇALVES, JFJR. and CALLISTO, M., 2010. What is more important for invertebrate colonisation in a stream with low-quality litter inputs: exposure time or leaf species? Hydrobiologia, vol. 654, no. 1, p. 125-136. http://dx.doi.org/10.1007/s10750-010-0375-8.

MAGURRAN, AE., 2004. Measuring Biological Diversity. Malden: Blackwell Science. $256 \mathrm{p}$.

MARTINELLI, LA. and KRUSCHE, AV., 2007. Amostragem de invertebrados bentônicos. In BICUDO, CEM. and BICUDO, DC. (Org.). Amostragem em Limnologia. vol. 2. São Carlos: Rima, p. 263-279.

MATHURIAU, C. and CHAUVET, E., 2002. Breakdown of leaf litter in a neotropical stream. Journal of the North American Benthological Society, vol. 21, no. 3, p. 384-396. http://dx.doi. org/10.2307/1468477.

MC CAFFERTY, WP., 1981. Aquatic Entomology. Boston: Jones and Bartlett Publishers. 448 p.

MERRITT, RW. and CUMMINS, KW., 1984. An introduction to the Aquatic Insects of North America. Dubuque: Kendall/Hunt publishing Co. $772 \mathrm{p}$.

MORETTI, MS., GONÇALVES JÚNIOR, JF., LIGEIRO, R. and CALLISTO, M., 2007. Invertebrates colonisation on native tree leaves in a Neotropical stream (Brazil). International Review of
Hydrobiology, vol. 92, no. 2, p. 199-210. http://dx.doi.org/10.1002/ iroh.200510957.

MORMUL, R.P., VIEIRA, L.A., PRESSINATTE-JUNIOR, S., MONKOLSHI, A. and SANTOS, AM., 2006. Sucessão de invertebrados durante o processo de decomposição de duas plantas aquáticas (Eichhornia azurea e Polygonum ferrugineum). Acta Scientiarum Biological Sciences, vol. 28, no. 2, p. 109-115.

OBERNDORFER, RY., MCARTHUR, JV., BARNES, JR. and DIXON, J., 1984. The effect of invertebrate predators on leaf litter processing in an alpine stream. Ecology, vol. 65, no. 4, p. 1325-1331. http://dx.doi.org/10.2307/1938337.

REICE, SR., 1980. The Role of Substratum in Benthic Macroinvertebrate microdistribution and litter decomposition in a woodland stream. Ecology, vol. 61, no. 3, p. 580-590. http:// dx.doi.org/10.2307/1937424.

RODRIGUES, RR. and NAVE, AG., 2001. Heterogeneidade florística das Matas Ciliares. In RODRIGUES, R.R. and LEITÃOFILHO, HF. (Ed.). Matas Ciliares: conservação e recuperação. 2nd ed. São Paulo: FAPESP. p. 45-71.

SANCHEZ, M., PEDRONI, F., LEITÃO-FILHO, HF. and CESAR, O., 1999. Composição florística de um trecho de floresta ripária na Mata Atlântica em Picinguaba, Ubatuba, SP. Revista Brasileira de Botânica, vol. 22, no. 1, p. 31-42.

SANSEVERINO, AM. and NESSIMIAN, JL., 2001. Habitats de larvas de Chironomidae (Insecta, Diptera) em riachos de Mata Atlântica no Estado do Rio de Janeiro. Acta Limnologica Brasiliensia, vol. 13, no. 1, p. 29-38.

SILVA, FL., MOREIRA, DC., BOCHINI, GL. and RUIZ, SS., 2008. Hábitos alimentares de larvas de Chironomidae (Insecta: Diptera) do córrego Vargem Limpa, Bauru, SP, Brasil. Biotemas, vol. 21, no. 2, p. 155-159. http://dx.doi.org/10.5007/21757925.2008v21n2p155.

SOUSA, BM. (Coord.), 2008. Plano de Manejo da Reserva Biológica Municipal Poço D'Anta, Juiz de Fora - MG. Juiz de Fora: ArcellorMittal Juiz de Fora/AGENDA JF/IEF. 357 p.

SWAN, CM. and PALMER, MA., 2004. Leaf diversity alters litter breakdown in a Piedmont stream. Journal of the North American Benthological Society, vol. 23, no. 1, p. 15-28. http://dx.doi. org/10.1899/0887-3593(2004)023<0015:LDALBI>2.0.CO;2.

SWAN, CM. and PALMER, MA., 2006. Composition of speciose leaf litter alters stream detritivore growth, feeding activity and leaf breakdown. Oecologia, vol. 147, no. 3, p. 469-478. http://dx.doi. org/10.1007/s00442-005-0297-8. PMid:16425049

WALLACE, JB. and WEBSTER, JR., 1996. The role of macroinvertebrates in stream ecosystem function. Annual Review of Entomology, vol. 41, no. 1, p. 115-139. http://dx.doi. org/10.1146/annurev.en.41.010196.000555. PMid:15012327

WOHL, DL., WALLACE, JB. and MEYER, JL., 1995. Benthic macroinvertebrate community structure, function and production with respect to habitat type, reach and drainage basin in the southern Appalachians (U.S.A.). Freshwater Biology, vol. 34, no. 3, p. 447-464. http://dx.doi.org/10.1111/j.1365-2427.1995.tb00902.x. 